\title{
Functional diversity of marine macrobenthic communities from sublittoral soft-sediment habitats off northern Chile
}

\author{
Aldo S. Pacheco • Maria Teresa González • \\ Julie Bremner • Marcelo Oliva • Olaf Heilmayer • \\ Jürgen Laudien $\cdot$ José M. Riascos
}

Received: 3 June 2010/Revised: 16 November 2010/Accepted: 17 November 2010/Published online: 3 December 2010

(C) Springer-Verlag and AWI 2010

\begin{abstract}
Benthic communities show changes in composition and structure across different environmental characteristics and habitats. However, incorporating species biological traits into the analysis can provide a better understanding of system functioning within habitats. We compare the functional diversity of macrobenthic communities from a contrasting shallow $(15 \mathrm{~m})$ and deep $(50 \mathrm{~m})$ sublittoral soft-sediment habitats in northern Chile, using biological traits analysis. Our aim was to highlight the biological characteristics responsible for differences between habitats and the implications for ecosystem functioning. Trait analysis showed that the deep habitat
\end{abstract}

Communicated by Luis Gimenez.

Electronic supplementary material The online version of this article (doi:10.1007/s10152-010-0238-8) contains supplementary material, which is available to authorized users.

A. S. Pacheco $(\bowtie) \cdot$ M. T. González · M. Oliva · J. M. Riascos Facultad de Recursos del Mar, Universidad de Antofagasta,

Av. Angamos 601, P.O. Box 170, Antofagasta, Chile

e-mail: babuchapv@yahoo.com

\section{J. Bremner}

Centre for Environmental, Fisheries and Aquaculture Science, Pakefield Road, Lowestoft, Suffolk NR33 0HT, UK

O. Heilmayer

International Bureau of the Federal Ministry of Education and

Research c/o German Aerospace Center (DLR), Bonn, Germany

J. Laudien

Alfred Wegener Institute for Polar and Marine Research,

27568 Bremerhaven, Germany

J. Laudien

Institute for Applied Ecology, GmbH,

18184 Broderstorf, Germany was restricted in providing functionally important biogenic structure and bioturbation and supports less diverse feeding-related energy pathways. The shallow habitat is characterized by more diverse energy pathways and a higher potential for matter exchange through bioturbation. We provide support to the predictions of transfer of energy from the benthos to upper trophic levels in the shallow, which is characterized mainly by normoxia and little organic matter content in the sediment. In the deep habitat, characterized by hypoxia and more organic matter, energy appears to be transferred to microbial components. We suggest that trait analysis should be added to the traditional approaches based on species diversity, because it provides indicators of ecosystem stress.

Keywords Ecosystem functioning - Biological traits . Upwelling · Invertebrates · Fuzzy coding

\section{Introduction}

Ecosystem functioning refers to the processes and properties shaping the energy flow through biotic and abiotic components of ecosystems (Díaz and Cabido 2001), thereby modulating the goods and services provided to humankind. These processes can be understood as a complex feedback system, where species are adapted to their physical and chemical environment, while the environment is constantly modified by species' biological activities (Levins and Lewontin 1985). A particular biotic community from a given habitat is a reflection of functional adaptation to the abiotic environment through evolutionary history (Levins and Lewontin 1985; Odling-Smee et al. 1996; Naeem 2002). Much information on ecosystem health, stability and persistence has been provided by 
studies examining benthic marine communities diversity and structure through time (e.g., Pearson and Rosenberg 1978; Collie et al. 2000; Warwick et al. 2002; Arntz et al. 2006; Pagliosa and Rodrigues 2006; Lancellotti and Stotz 2004). However, diversity provides rather limited information about ecosystem properties (Díaz and Cabido 2001) because it describes only which or how many species are present in the system, but not their functional relevance. Measurements of species roles provide a useful alternative to the more traditional species-based methods. Commonly, functional approaches classify taxa into trophic groups (Fauchald et al. 1979; Pagliosa 2005), which indicate, for instance, the sources of food supply operating in the ecosystem. Likewise, trophic relationships have been used to model the distribution and efficiency of the energy and matter flow through benthic systems (Christensen and Pauly 1993) and the dynamics of biomass change (Ortiz and Wolff 2002a, b; Taylor et al. 2008). The species roles, or traits, serve as indicators of the trophic function of the system.

Although functional groups can integrate a large number of biological traits, they are often defined by only a small number of traits (e.g., feeding mechanisms), thus ignoring other important characteristics. For instance, in the studies of subtidal rocky communities, sponges, bryozoans, bivalves and barnacles are often grouped as suspension or filter feeders (Witman and Dayton 2001). However, these taxa exhibit different strategies of growth and space colonization: while sponges and bryozoans are colonial species that occupy space by lateral growth, barnacles and bivalves mainly depend on gregarious recruitment for space occupation (Jackson 1977; Sebens 1982, 1986). In soft-bottom habitats, trophic-based studies may overlook key functions, such as nutrient cycling, that are often biologically driven (the bioturbatory activities of benthic species affect sediment geochemistry, see Reise 1985; Levinton 1995; Heip et al. 2001; Lohrer et al. 2005) and habitat provision (habitat engineering and bio-construction, see Jones et al. 1994; Meysman et al. 2002; Reise 2002; Lomovasky et al. 2006). In this context, knowledge of multiple aspects of ecosystem function can be attained by considering as many functionally important traits as possible (Norling et al. 2007).

One approach attempting such a task is biological traits analysis (BTA), which uses the occurrence of species' traits as indicators of aspects of system function. Multi-trait approaches such as BTA have found use in ecosystem ecology for describing spatial and temporal patterns of benthic functioning and their relation to environmental variability, as well as the functional consequences of anthropogenic activities (see Norling et al. 2007; Marchini et al. 2008, Bremner 2008 and references therein; de Bello et al. 2010). Traits serve as indicators of specific aspects of ecosystem function (e.g., trophic traits indicate the flow of energy and carbon through a system), selected on the basis of published evidence and/or expert judgment. The inclusion of indicators of multiple functions means that BTA gives a good view of overall function in a system and how this function may respond to natural or anthropogenic change.

In this study, we investigated sublittoral benthic communities from Mejillones Bay, in the highly productive coastal Humboldt Current system off northern Chile (Escribano 1998; Escribano and Hidalgo 2000; Giraldo et al. 2002). The system is characterized by the presence of oxygen minimum zones (OMZ; $<0.5 \mathrm{ml} \mathrm{O}_{2}^{-1}$ ), because primary production exceeds bacterial re-mineralization capacity and organic matter oxidation during its passage from the water column to the bottom and to the presence of persistent upwelled oxygen-deficient waters (Barber and Smith 1981; Tarazona and Arntz 2001; Thiel et al. 2007). Along the coastal shelf off northern Chile, hypoxic conditions extend from shallow subtidal waters $(30 \mathrm{~m})$ to deeper zones $(500 \mathrm{~m})$ (Valdés et al. 2006; Laudien et al. 2007), thus creating a depth stratified environment that strongly modulates species' adaptations, community composition and structure (Palma et al. 2005; Sellanes et al. 2007). Indeed, it provides an excellent natural scenario to test predictions about how coastal ecosystems may respond to the worrying spread of anthropogenic eutrophication and hypoxia (see review in Diaz and Rosenberg 2008). Off northern Chile, taxa composition differs substantially between shallow ( $<20 \mathrm{~m}$, Laudien et al. 2007) and deep ( $>50 \mathrm{~m}$, Palma et al. 2005; Quiroga et al. 2005) areas of the bay as several calcified invertebrates (e.g., mollusks, echinoderms, cnidarians and crustaceans) are less tolerant to hypoxia (Levin 2003; Arntz et al. 2006). However, we have little understanding about how these two habitats differ in their functioning or, indeed, the functional consequences of hypoxia.

Here, we study the functional traits of macrobenthic communities in shallow and deep habitats off Mejillones bay for the first time. As the two habitats represent differing environmental conditions (shallow, normoxic vs. deep, hypoxic), it is postulated that functioning should also differ. In terms of ecosystem functioning, we test predictions proposed by Diaz and Rosenberg (2008) that in normoxic habitats benthic energy is transferred to higherlevel predators and communities are in advance states of successional maturity, while in hypoxic conditions energy flows toward microbes and communities are in early maturity. The objectives of this study were (1) to describe the functional trait composition of macrobenthic communities from these two sites with differing environmental conditions and (2) to discuss the implications of any differences in these traits for benthic ecosystem functioning. 


\section{Materials and methods}

Study area and environmental parameters

The macrobenthic community was sampled from two permanent stations at Punta Chacaya at the northern side of Mejillones Bay $\left(22^{\circ} 59^{\prime} \mathrm{S}, 70^{\circ} 20^{\prime} \mathrm{W}\right.$; Fig. 1). This bay is characterized by cold upwelled waters, rich in nutrients and a shallow $(0-200 \mathrm{~m})$ poleward flow which enhances water recirculation inside the bay (Marin et al. 2001; Escribano et al. 2002). Sea surface temperature ranges between 13.5 and $22^{\circ} \mathrm{C}$ in winter and summer, respectively (Laudien et al. 2007). Replicated samples $(N=4)$ were randomly taken each month from August 2006 to March 2007 using a $0.1-\mathrm{m}^{2}$ Van Veen grab. Three grab sediment samples were washed on a 500- $\mu \mathrm{m}$ mesh screen and the retained biota transferred to plastic bags and fixed with $10 \%$ buffered formalin containing Rose Bengal $\left(10 \mathrm{mg} \mathrm{l}^{-1}\right)$. In the laboratory, all animals were identified to the lowest taxonomic level with the help of a binocular stereoscope and relevant taxonomic literature. Thereafter, biomass of the organisms was determined by weighing all taxa (mass at $0.01 \mathrm{~g}$ precision) after blotting on filter paper. In order to use size as a trait, weights were determined separately for individual taxa (see following section). A fourth sample was taken for the measurements of total organic matter and particle-size analysis. Organic matter was calculated as a percentage of weight loss after burning $10 \mathrm{~g}$ of sediment at $550^{\circ} \mathrm{C}$ for $4 \mathrm{~h}$ in a muffle furnace. Particle-size analysis consisted in sieving $100 \mathrm{~g}$ through geological sieves (from 4 to $0.063 \mathrm{~mm}$ ) and classified according to the Wentworth scale (Buchanan 1984). Granulometric parameters values such as sorting degree, graphic average and graphic asymmetry were obtained following Folk and Ward (1957). In addition, at each sampling station, a CTD (Seabird 19) equipped with a Beckman oxygen sensor was used to measure water temperature, salinity and oxygen content at $\sim 0.5 \mathrm{~m}$ above the sea floor. Biogenic structures (e.g., shell pieces) present in the sediment were also noted. Principal component analysis (PCA) was performed to visualize the patterns of resemblance between habitats. The PCA was based on Euclidean distances on normalized data $\left(X_{n}=X-X / \mathrm{SD}\right)$ to account for scale differences between variables. Additionally, variable vectors were superimposed to the PCA biplot, and the length and direction of vectors were assessed to evaluate the contribution of each environmental variable to each PC.

\section{Biological traits analysis (BTA)}

Thirteen biological traits were selected for analysis and divided into a total of 53 categories, following Bremner et al. (2003, 2006) (Table 1). The selected traits reflected species life history, morphology, ecological adaptations

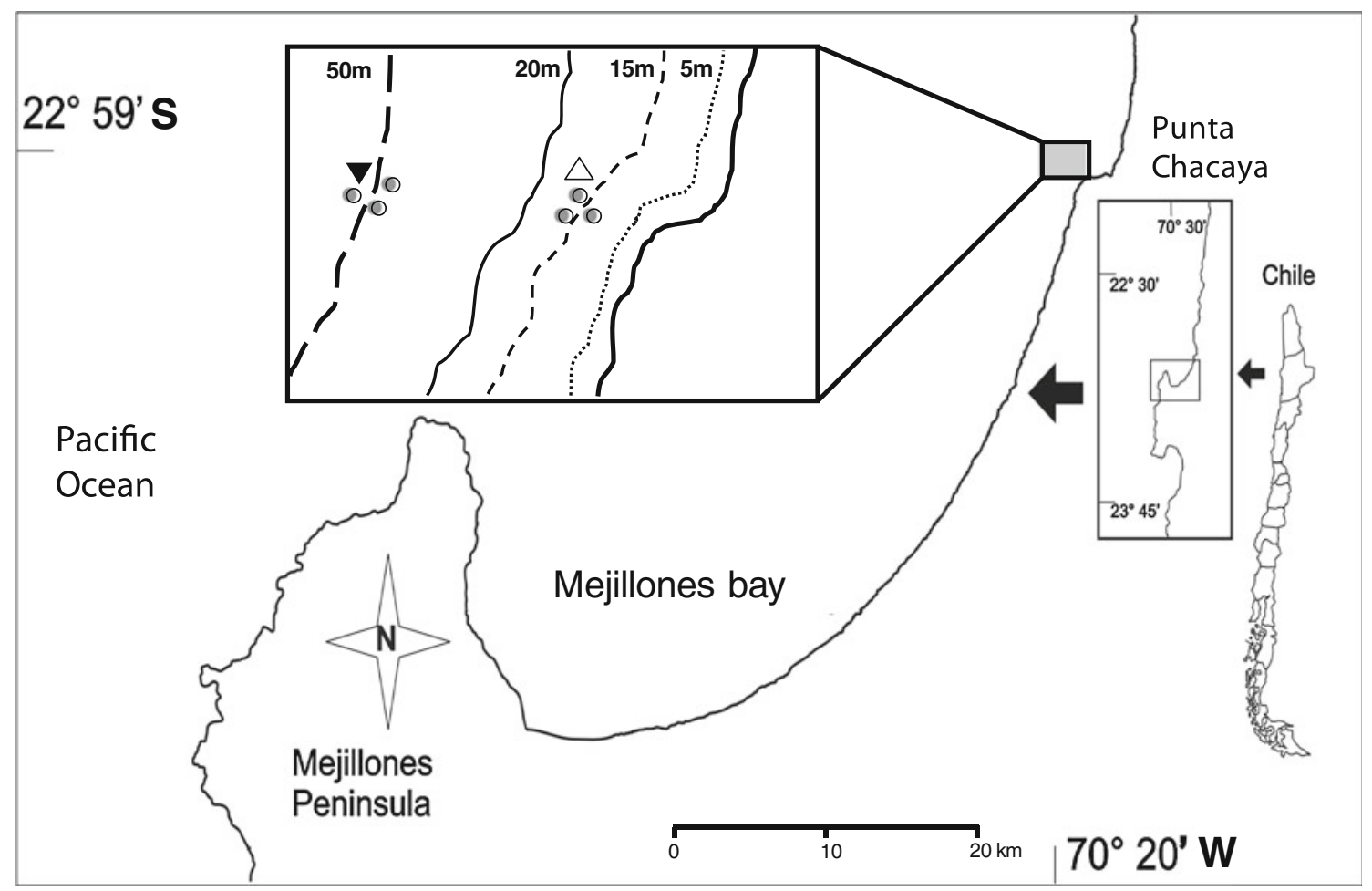

Fig. 1 Location of the sampling stations near Punta Chacaya in the north of Mejillones Bay. The gray circles show the shallow (open triangle) and deep (inverted filled triangle) habitats 
Table 1 Biological trait variables and categories used to describe functioning diversity of macrobenthic communities off Punta Chacaya

\begin{tabular}{|c|c|}
\hline Trait & Category \\
\hline $\begin{array}{l}\text { Size (measured as body } \\
\text { mass }[\mathrm{gr}] \text { ) }\end{array}$ & $\begin{array}{l}\text { Small }(0.0001-0.01) \\
\text { Medium-small }(0.02-0.1) \\
\text { Medium-large }(0.2-1) \\
\text { Large }(>2)\end{array}$ \\
\hline Longevity (years) & $\begin{array}{l}0-3 \\
4-7 \\
8-11 \\
>12\end{array}$ \\
\hline Reproductive mode & $\begin{array}{l}\text { Asexual reproduction } \\
\text { Sexual reproduction-shed eggs } \\
\text { Sexual reproduction-brood eggs }\end{array}$ \\
\hline Propagule dispersal & $\begin{array}{l}\text { Pelagic dispersal } \\
\text { Benthic dispersal }\end{array}$ \\
\hline Body design & $\begin{array}{l}\text { Soft } \\
\text { Soft-protected (tube/tunic cover) } \\
\text { Hard exoskeleton } \\
\text { Hard shell }\end{array}$ \\
\hline Living habitat & $\begin{array}{l}\text { Tube } \\
\text { Permanent burrow } \\
\text { Temporary burrow } \\
\text { Crevice/hole/under stone } \\
\text { Epizoic/epiphytic } \\
\text { Free }\end{array}$ \\
\hline Living location/position & $\begin{array}{l}\text { Surface } \\
\text { Interface } \\
\text { Infauna: } 0-5 \mathrm{~cm} \\
\text { Infauna: } 6-10 \mathrm{~cm} \\
\text { Infauna: }>10 \mathrm{~cm}\end{array}$ \\
\hline Exposure potential & $\begin{array}{l}\text { Low (infauna or flat interface) } \\
\text { Moderate (mound interface) } \\
\text { High (erect interface) }\end{array}$ \\
\hline Degree of attachment & $\begin{array}{l}\text { None } \\
\text { Temporary }\end{array}$ \\
\hline Feeding strategy & $\begin{array}{l}\text { Carnivore } \\
\text { Filter feeders } \\
\text { Interface feeders } \\
\text { Surface deposit feeders } \\
\text { Subsurface deposit feeders } \\
\text { Carnivore/surface deposit feeders } \\
\text { Omnivore/carnivore } \\
\text { Commensalist/surface deposit feeders }\end{array}$ \\
\hline Movement method & $\begin{array}{l}\text { None } \\
\text { Swim } \\
\text { Crawl/creep/climb } \\
\text { Burrow } \\
\text { Jump }\end{array}$ \\
\hline
\end{tabular}

Table 1 continued

\begin{tabular}{ll}
\hline Trait & Category \\
\hline Mobility & Sessile \\
& Motile \\
Habitat structuration & None \\
& Form-settlement/attachment site \\
& Form-shelter \\
& Action-sediment accretion \\
& Action-sediment removal
\end{tabular}

Traits were chosen following Bremner et al. (2006)

and behavior. Individual taxa were coded for categories of each trait using a fuzzy-coding procedure (Chevenet et al. 1994). The scoring range of 0 to 3 was used, with 0 meaning no affinity to a trait category and 3 being total affinity (the complete species trait's coding is provided as supplementary data). For instance, the polychaete Diopatra chilensis is mostly a carnivore but can occasionally act as an omnivore, so it was coded 3 (carnivore), 0 (interface feeder), 0 (filter feeder), 0 (surface deposit feeder), 0 (subsurface deposit feeder), 1 (omnivore) and 0 (commensal/surface deposit feeder) for the trait variable "feeding strategy". Information used for coding was gathered form relevant literature and the assistance of experts of the different taxa. Fuzzy correspondence analysis (FCA) was chosen to evaluate differences in traits between shallow and deep habitats. This ordination method uses eigenvalues to reveal differences between samples, based on the biological traits exhibited by each species present in each habitat, weighted by their abundance (Chevenet et al. 1994). FCA analysis allows the identification and visualization of traits contributing to the differences or similarities between communities in a biplot (Chevenet et al. 1994). For BTA analyses, a FCA was performed using 54 trait categories (weighted by species abundances) and 6 samples belonging to 2 habitats (shallow vs. deep). In this FCA, the significance of the ordinations was tested using a chi-square statistic (Vivanco 1999; Quinn and Keough 2002). This analysis consider an $n \times m$ matrix $Y$, with elements $Y_{i j}$, rows $Y_{i}^{T}$ and columns $Y_{(j)}$ of $n$ observations on $m$ variables centered on the column means. Then, biplot consists of two-element vectors $a_{i}^{T}$, and $b_{j}^{T}$ s for the $n$ rows and $m$ columns, respectively, and whose inner products approximate the elements (Gabriel 1971, 2002). Thus, the points in the same vicinity (same quadrants) are used to determine the association between the categories, allowing a visual examination of the structure or pattern of these associations (Vivanco 1999). 
As long-term studies of benthic community structure in northern Chile have shown little or no seasonal oscillations, with main changes associated with interannual climate variability (e.g., Carrasco 1997; Laudien et al. 2007; Carrasco and Moreno 2006), an eight-month period was considered enough to characterize the macrobenthic community. A preliminary correspondence analysis using community structure (log-transformed $(\log (X+1))$ species abundances) among months within stations showed no significant differences neither at shallow $\left(\chi^{2}=102.87\right.$; $d f=245 ; P>0.99)$ nor at the deep habitat $\left(\chi^{2}=19.71\right.$; $d f=70 ; P>0.99)$, except by some few species, which were most abundant in some months (Fig. 2). These analyses confirmed our assumption of no marked seasonality; thus, monthly samples were pooled. Therefore, the final analysis was based on total abundances per replicate from
Fig. 2 Correspondence analysis ordination plots based on monthly species abundances obtained during the months of study in each habitat. Upper plot shallow habitat (open triangle), below deep habitat plot (inverted filled triangle). Full scientific names are presented in Table 3
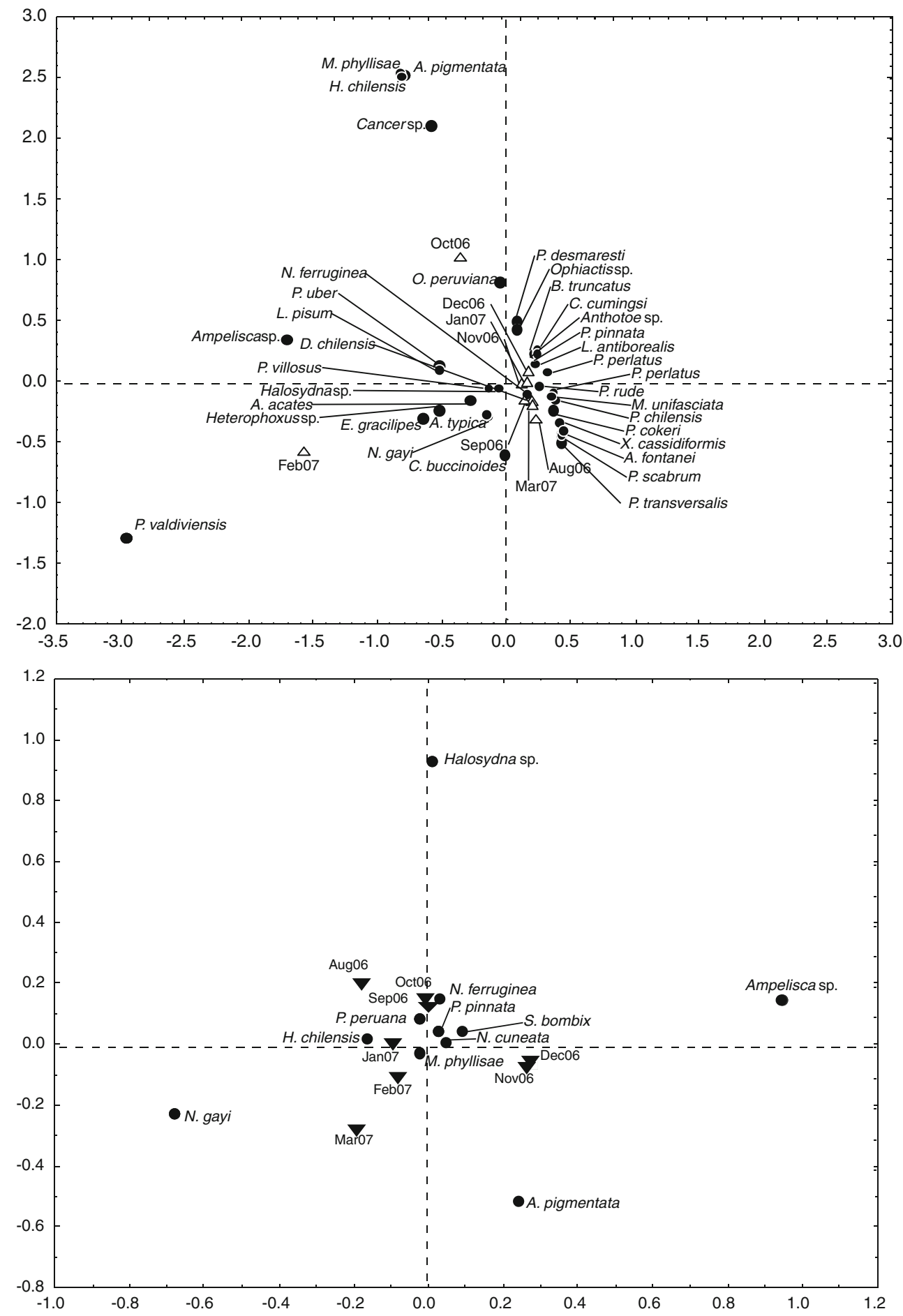
each habitat. We justified such grouping because variations within stations are retained, giving a more informative comparison between habitats. Statistical analyses were performed using the software Statistica 6.0.

\section{Results}

\section{Stations' environmental characteristics}

Sediments in the shallow station were composed of poorly sorted fine sand, with moderate excess of gross particles. Large quantities of broken shells of the scallop Argopecten purpuratus were usually present, together with mats of the red algae Rhodymenia corallina. The sediment of the deep habitat consisted of well-sorted very fine sand with moderate gross excess. Sediments were dark brown/black in color, exhibiting a sulfur smell, and mats of the giant benthic bacteria Thioploca spp. were often present. The content of total organic matter was higher in deep sediments than in the shallow station. Bottom waters were warmer and well oxygenated at the shallow station, while deep waters were comparatively cooler and less oxygenated. Hypoxic conditions $\left(<0.5 \mathrm{ml} \mathrm{O}_{2} \mathrm{l}^{-1}\right)$ were registered three times during November and December 2006 and January 2007 in the deep habitat. Salinity values did not show strong fluctuations between habitats during the study period. Table 2 provides a summary of the environmental parameters. Figure 3 shows the PCA biplot, in which PC1 accounted for $61.4 \%$ of the variability and $\mathrm{PC} 2$ a further $19.7 \%$, thus accounting for $81.1 \%$ of the environmental variability between them. The length and direction of the superimposed variable vectors indicated that PC1 was weighted with a combination of bottom temperature, dissolved oxygen and total organic matter content. Sediment parameters such as sorting degree and graphic average were situated in the positive direction of the PC2 axis, while salinity and graphic asymmetry values increased toward negative values of this axis. These results suggest that temperature, oxygen and organic matter are strongly related to depth, while salinity and granulometric parameters did not produce important variation in depth. The environmental parameters together describe a depth stratified habitat which might influence the composition of communities and functioning.

Species composition, abundance and biological traits distributions

In total, 39 species were recorded from both habitats, comprising diverse phyla such as Polychaeta, Cnidaria, Crustacea, Echinodermata and Mollusca. A very similar community composition has been reported at different
Table 2 Summary of the environmental parameters values (mean and standard deviation) registered in both studied habitats in the sublittoral zone off Punta Chacaya

\begin{tabular}{lll}
\hline & $\begin{array}{l}\text { Shallow }(15 \mathrm{~m}) \\
X \pm \mathrm{SD}\end{array}$ & $\begin{array}{l}\text { Deep }(50 \mathrm{~m}) \\
X \pm \mathrm{SD}\end{array}$ \\
\hline Temperature $\left({ }^{\circ} \mathrm{C}\right)$ & $15.4 \pm 0.62$ & $13.0 \pm 0.47$ \\
Dissolved oxygen $\left(\mathrm{ml}_{2}^{-1}\right)$ & $2.6 \pm 0.92$ & $0.6 \pm 0.27$ \\
Total organic matter $(\%)$ & $1.4 \pm 0.24$ & $3.31 \pm 0.46$ \\
Salinity (PSU) & $34.5 \pm 0.17$ & $34.8 \pm 0.07$ \\
Grain size (mm) & & \\
4 & $0.4 \pm 1.13 \%$ & $0 \%$ \\
2 & $2.35 \pm 2.82 \%$ & $0.49 \pm 0.35 \%$ \\
1 & $2.46 \pm 1.77 \%$ & $0.51 \pm 0.24 \%$ \\
0.5 & $3.99 \pm 5.16 \%$ & $1.48 \pm 1.37 \%$ \\
0.25 & $8.88 \pm 1.5 \%$ & $2.98 \pm 1.11 \%$ \\
0.125 & $48.95 \pm 1.4 \%$ & $34.91 \pm 4.77 \%$ \\
0.063 & $17.79 \pm 1.54 \%$ & $50.30 \pm 4.07 \%$ \\
$<0.063$ & $13.44 \pm 1.4 \%$ & $6.40 \pm 3.34 \%$ \\
Graphic average & $2.69 \pm 0.44$ & $3.06 \pm 0.17$ \\
Sorting degree & $1.01 \pm 0.49$ & $0.73 \pm 0.1$ \\
Graphic asymmetry & $-0.13 \pm 0.13$ & $-0.18 \pm 0.08$ \\
Biogenic structures & Shell pieces, & Thioploca sp. mats \\
& Rhodymenia & \\
& coralline & \\
\hline & &
\end{tabular}

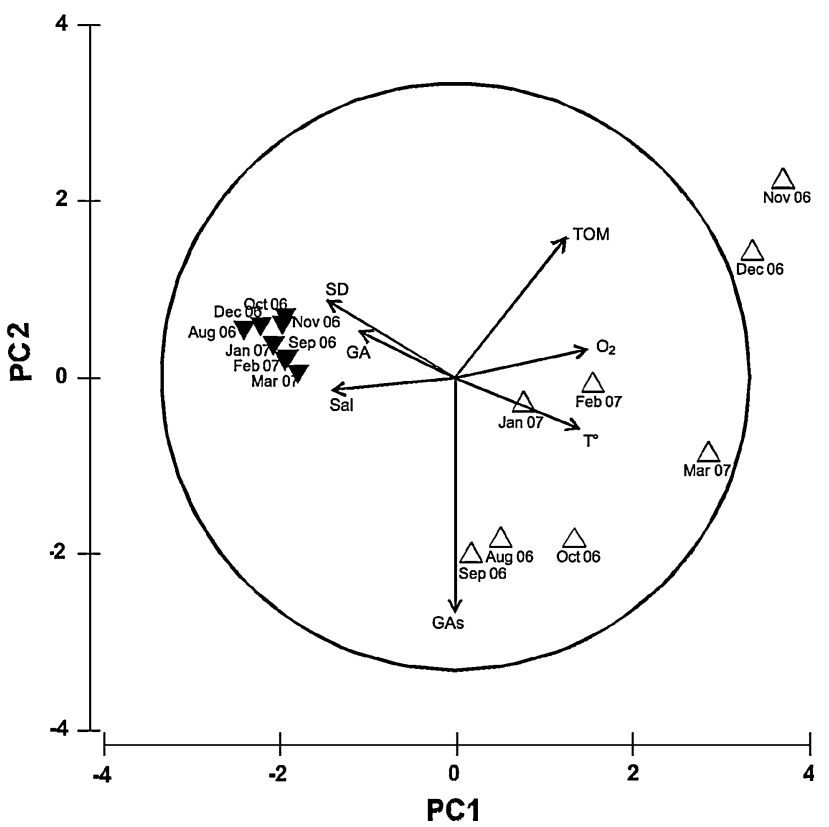

Fig. 3 Principal component analysis biplot from the environmental parameters recorded during the study period. Shallow (open triangle) and deep (inverted filled triangle) habitats. Total organic matter (TOM), dissolved oxygen $\left(\mathrm{O}_{2}\right)$, temperature $\left(\mathrm{T}^{\circ}\right)$, salinity (Sal), graphic average (GA), sorting degree (SD) and graphic asymmetry (GAs) 
locations within the bay (e.g., Laudien et al. 2007) and elsewhere in the northern of Chile coast (e.g., Quiroga et al 1999; Carrasco 1997; Carrasco and Moreno 2006; Moreno et al. 2008); thus, our study can be considered representative of sublittoral sediments of this geographic region. Thirty-six species from all phyla were recorded in the shallow normoxic habitat, while in the deep hypoxic habitat eleven species were registered, representing mainly Polychaeta (Table 3). Eight species were present in both habitats (Nepthys ferruginea, Haploscoloplos chilensis, Magelona phyllisae, Aricidea pigmentata, Halosydna sp., Ampelisca sp., and Nassarius gayi). The species Prionospio peruana, Spiophanes bombix and Nuculeana cunata were recorded exclusively in the deep hypoxic habitat. The major difference in terms of taxa composition between habitats was the lack of Cnidaria, Crustacea, Echinordermata and Mollusca in the deep habitat (Table 3). In the shallow normoxic habitat, the most abundant species were
Table 3 List of species and abundance (ind $/ \mathrm{m}^{-2}$ ) recorded during the study
Values are the mean and standard deviation of the species recorded in both studied habitats

\begin{tabular}{|c|c|c|c|c|}
\hline Phylum & Family & Species & Shallow & Deep \\
\hline \multirow[t]{9}{*}{ Polychaeta } & Nephtyidae & Nephtys ferruginea & $9.67 \pm 3.06$ & $139 \pm 65.21$ \\
\hline & Onuphidae & Diopatra chilensis & $29.67 \pm 5.69$ & 0 \\
\hline & Orbiniidae & Haploscoloplos chilensis & $2.33 \pm 3.21$ & $105.33 \pm 57.1$ \\
\hline & Magelonidae & Magelona phyllisae & $0.33 \pm 0.58$ & $1,578 \pm 523.54$ \\
\hline & Paraonidae & Aricidea pigmentata & $0.33 \pm 0.58$ & $72.33 \pm 37.63$ \\
\hline & Polynoidae & Halosydna sp. & $59 \pm 11.36$ & $0.67 \pm 1.115$ \\
\hline & Spionidae & Paraprionospio pinnata & $16 \pm 12.29$ & $2,024.67 \pm 447.92$ \\
\hline & Spionidae & Prionospio peruana & 0 & $510.33 \pm 183.65$ \\
\hline & Spionidae & Spiophanes bombyx & 0 & $309 \pm 109.23$ \\
\hline \multirow[t]{2}{*}{ Cnidaria } & Sagartiidae & Anthothoe sp. & $1,580.67 \pm 470.1$ & 0 \\
\hline & Actinostolidae & Antholoba achates & $1.33 \pm 1.53$ & 0 \\
\hline \multirow[t]{14}{*}{ Crustacea } & Ampeliscidae & Ampelisca sp. & $28.67 \pm 28.29$ & $4 \pm 4$ \\
\hline & Phoxocephalidae & Heterophoxus sp. & $19.67 \pm 13.43$ & 0 \\
\hline & Aoridae & Aora typica & $89 \pm 30.30$ & 0 \\
\hline & Platyischnopidae & Eudevenopus gracilipes & $9.67 \pm 5.51$ & 0 \\
\hline & Alpheidae & Betaeus truncatus & $51.67 \pm 17.67$ & 0 \\
\hline & Paguridae & Pagurus villosus & $85 \pm 43$ & 0 \\
\hline & Paguridae & Pagurus perlatus & $89 \pm 77.32$ & 0 \\
\hline & Xanthidae & Pilumnoides perlatus & $5.67 \pm 3.06$ & 0 \\
\hline & Platyxanthidae & Platyxanthus cokeri & $76.33 \pm 35.13$ & 0 \\
\hline & Porcellanidae & Petrolisthes desmaresti & $23.67 \pm 31.94$ & 0 \\
\hline & Hippolytidae & Latreutes antiborealis & $3.67 \pm 2.08$ & 0 \\
\hline & Pinnotheridae & Pinnixa transversalis & $1.33 \pm 1.53$ & 0 \\
\hline & Pinnotheridae & Pinnixa valdiviensis & $4.67 \pm 1.15$ & 0 \\
\hline & Cancridae & Cancer sp. & $11.67 \pm 2.52$ & 0 \\
\hline \multirow[t]{2}{*}{ Echinodermata } & Ophiactidae & Ophiactis sp. & $6 \pm 2$ & 0 \\
\hline & Asterinidae & Patiria chilensis & $0.67 \pm 0.58$ & 0 \\
\hline \multirow[t]{12}{*}{ Mollusca } & Chitonidae & Chiton cumingsi & $8 \pm 6.08$ & 0 \\
\hline & Buccinidae & Aeneator fontanei & $2.67 \pm 3.06$ & 0 \\
\hline & Columbellidae & Mitrella unifasciata & $1,347.67 \pm 75.14$ & 0 \\
\hline & Nassariidae & Nassarius gayi & $128.67 \pm 13.28$ & $23.33 \pm 7.77$ \\
\hline & Cancellaridae & Cancellaria buccinoides & $6.33 \pm 4.51$ & 0 \\
\hline & Ranellidae & Priene rude & $60.33 \pm 18.9$ & 0 \\
\hline & Ranellidae & Priene scabrum & $20.67 \pm 8.08$ & 0 \\
\hline & Olividae & Oliva peruviana & $2.67 \pm 2.52$ & 0 \\
\hline & Naticidae & Polinices uber & $2 \pm 1.73$ & 0 \\
\hline & Muricidae & Xanthochorus cassidiformis & $0.67 \pm 1.15$ & 0 \\
\hline & Nuculanidae & Nuculana cuneata & 0 & $862 \pm 214.3$ \\
\hline & Nuculinae & Linucula pisum & $3.33 \pm 3.06$ & 0 \\
\hline
\end{tabular}




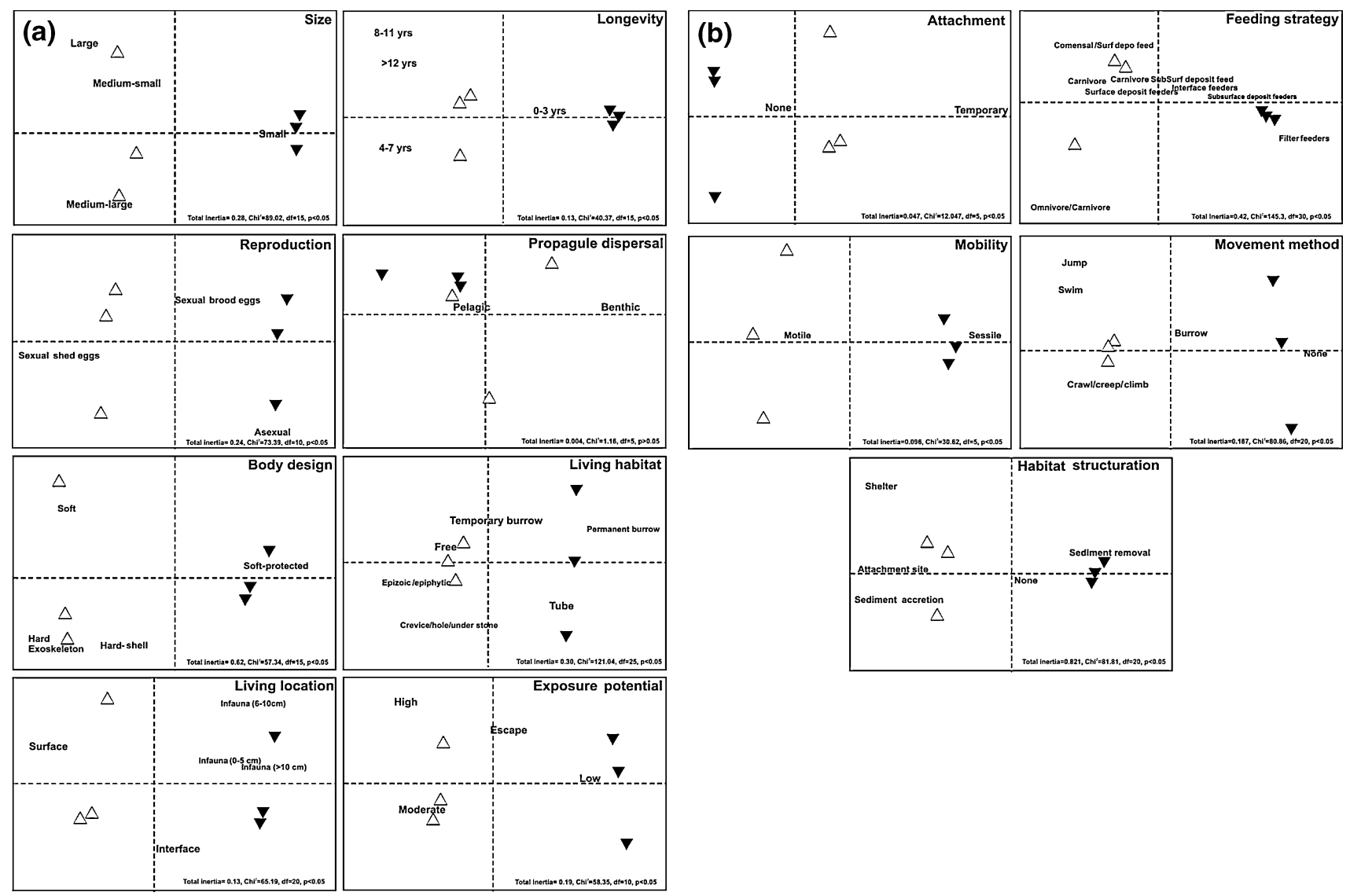

Fig. 4 Ordination of the biological trait categories obtained from the fuzzy correspondence analysis. Shallow (open triangle) and deep (inverted filled triangle) habitats

(in decreasing order) as follows: Anthothoe sp., Mitrella unifasciata, Nassarius gayi, Pagurus perlatus, Platyxanthus cokeri and Halosydna sp., while Paraprionospio pinnata, Magelona phyllisae, Nuculana cuneata, Prionospio peruana and Nepthys ferruginea numerically dominated in the deep habitat (Table 3). Simple FCA analysis (6 samples vs. 53 trait categories) (see Table 1) showed significant trait differences between habitats (total inertia $=0.192$; $\left.\chi^{2}=1,391.1 ; \quad d f=280, \quad P<0.001\right)$. Individual plots allowed an easy visualization of the differences between trait categories (Fig. 4a, b). Traits values associated with the shallow normoxic habitat were large and medium (size), $8-11$ and $>12$ years (longevity), sexual-shed eggs (reproduction), soft, hard-exoskeleton and hard-shell (body design), temporary burrow, free, epizoic/epiphytic, crevice/ hole/under stone (living habitat), surface (living location), high, escape, moderate (exposure potential), omnivore/ carnivore (feeding strategy), jump, swim, crawl/creep/limb (movement method), motile (mobility), shelter, attachment site and sediment accretion (habitat provision). Traits associated exclusively with the deep hypoxic habitat were small (size), 0-3 years (longevity), asexual (reproduction), soft (body design), soft-protected (body design), permanent burrow and tube (living habitat), infauna (living location), low (exposure potential), filter feeders, subsurface deposit feeders (feeding strategy), burrow (movement method), sessile (mobility), sediment removal (habitat structuration). No significant association was found in the categories corresponding to propagule dispersal.

\section{Discussion}

This study indicates that the functional composition of macrobenthic invertebrate communities from shallow and deep sublittoral habitats off Mejillones Bay differs, thus suggesting differences in ecosystem properties and functioning. Differences in the relative proportions of functional traits between these habitats are in line with the habitat templet and environmental filtering concepts, which state that the environment dictates community assembly through selection of specific species traits (Southwood 1977; Townsend and Hildrew 1994; Townsend et al. 1997). In our studied system, the differences in traits are the reflection of the gradient in community structure influenced by environmental parameters such as depth, dissolved 
oxygen, organic matter content, bottom temperature and the presence of biogenic structures. In this sense, traits analysis succeeds in showing a disturbed versus less-disturbed situation between habitats in relation to oxygen status. Traits such as "small size", "short-lived" "burrowing" and "infauna" were associated with the deep hypoxic habitat, rather than the shallow normoxic site. These traits were common in areas disturbed by trawl fisheries (e.g., Tillin et al. 2006; Kenchington et al. 2007). The community of the shallow habitat was characterized by traits such as "large-sized", "long-lived epifauna" which, in the context of trawling and dredging activities, are associated with un-impacted or low-impact conditions (Thrush and Dayton 2002). The preponderance of specific biological traits in impacted habitats is a major concern because it may signify an important degree of habitat homogenization and thus symptoms of low biodiversity. In the same line, our BTA supports the predictions by Diaz and Rosenberg (2008) regarding successional maturity. The shallow station resembled advanced successional states with typical K-strategy species characteristics that are found in normoxic conditions, while at the deep and often hypoxic station, species traits were similar to r-strategy characteristics and thus in early states of successional development (Diaz and Rosenberg 2008).

The biogenic structure observed in the samples provides another important difference between habitats. Biotic structures can provide habitat for other species (e.g., shell litter, the filamentous red algae and the giant filamentous bacteria Thioploca sp.), therefore potentially enhancing the bottom surface complexity and thus having implications on functioning. The red algae Rhodymenia corallina was found in the shallow habitat. Algae fix carbon from the environment and serve as food for consumers but they can also serve as a refuge and settlement substrate for epifaunal organisms. Furthermore, Rhodymenia corallina inserts their rhizoids inside the bottom contributing to spatial sediment stability. In the deep habitat, Thioploca sp. can develop large sheaths and trichomes inserted $5 \mathrm{~cm}$ into the sediment but also protruding from the surface (Jørgensen and Gallardo, 1999). As Thioploca sp. may reach high biomass levels $(1 \mathrm{~kg}$ per $\mathrm{m}^{2}$ wet mass, Arntz et al. 2006, Pacheco unpublished data), this giant bacteria may play a significant role in sediment stability. In hypoxic soft bottoms off northern Chile, the oxidation of the rich organic matter produces hydrogen sulfide, which is utilized by Thioploca $\mathrm{sp}$. in the denitrification process during anaerobic respiration (Ferdelman et al. 1997; Jørgensen and Gallardo 1999). The sulfur bacteria thus have the capability to detoxify the surface sediment by taking up most of the toxic hydrogen sulfide, which may facilitate life of aerobic species under hypoxic conditions (Arntz et al. 2006).
Traits reflecting the species capability of habitat modification through their activities (i.e., bioturbation) also provide interesting insights about ecosystem functioning. In the shallow habitat, species inhabited the shallowest layer of the sediment, the surface, or settled on biogenic hard structures (e.g., shells pieces). In addition, they formed temporary burrows, were motile and able to displace themselves by several manners (e.g., jumping, swimming, crawling, creeping and climbing) and were capable of sediment accretion. These traits together with the predominant large size suggested activities in which the sediment surface is permanently disrupted. This may contribute to the increase in the rate of particle exchange between the water column and sediment (e.g., Sandnes et al. 2000) influencing the interchange of matter in benthic-pelagic coupling and biogeochemical cycles (Lohrer et al. 2004). In the same line, species thriving in the deep habitat removed sediment were infaunal, sessile (in the sense of limited displacement), burrowers or small in size. These traits suggest that there is a potential for water penetration into the sediment surface which may provide organic matter to lower sediment layers where it can be decomposed and also incorporate oxygen in the sediment. However, as there is little oxygen in the bottom water, it may be argued that this type of bioturbation is not so important for ecosystem functioning. Gutiérrez et al. (2000) found that bioturbation potential of macrobenthic communities under hypoxia during intense upwelling condition is rather weak and only improves with oxygenation events during El Niño conditions. Nonetheless, the contribution of bioturbators may help the aerobic functioning at some level even in hypoxia.

Biological trait analysis, as shown here, does not characterize the food web itself, as this requires the analysis of several other biotic (i.e., micro-, meio- and mega-fauna) and abiotic (i.e., nutrients) components. Rather, it provides insights into the interactions between different species and their food sources. Feeding traits also suggest differences in functioning. In the shallow habitat, the presence of carnivores, commensalist/surface deposit feeders, surface deposit feeders and omnivores/carnivores indicate diverse food sources. In the deep habitat, the presence of subsurface deposit feeders and interface feeders suggests that the main food source is the organic matter suspended in the water column and deposited in the sediment. As the method of capture and supply of food for macrobenthic species differ in both habitats, the energy flux might have distinct pathways within both systems. According to Ulanowicz (1986, 1997), the more feeding traits (i.e., more sources of food) are detected, the more diverse pathways of energy and matter cycling are expected. There may be interdependency for food resources between species in the shallow habitat, in comparison with the deep habitat that 
seems to be dependent of the external input of food. Likewise, our results also support the prediction the benthos in normoxic conditions-as seen in our shallow habitat-may transfer energy to mobile predators, while in the deep and hypoxic habitat, energy is mainly transferred to microbes (Diaz and Rosenberg 2008).

Analysis of traits related to reproduction, propagule dispersal and attachment permit, to some degree, inferences about the transport of matter within and between systems. For example, pelagic dispersion was represented in both habitats, suggesting that the supply of propagules via the water column is an important form of matter export that contributes to bentho-pelagic coupling in both systems. It is worth noting that both habitats supported traits suggesting input of matter within the benthic habitat. This can be seen in the benthic dispersion and shedding eggs traits in the shallow habitat, while the asexual trait may perform this function in the deep habitat. The asexual reproduction trait was accounted for by the autotomy capacity detected in the polychaete assemblage from the deep habitat.

To our knowledge, this is the first attempt to evaluate functional composition in sublittoral soft-bottom macrobenthic communities of the Chilean coast. There is a growing concern about the spread of anthropogenically created hypoxic-anoxic areas leading to a considerable reduction in benthic biomass (Diaz and Rosenberg 2008). Our study area is hypoxic due to the combination of naturally high productivity and oxygen-depleted waters of the upwelling system, which can be enhanced by the nutrient inputs produced in coastal cities. Considering that the main benthic fisheries resources are captured from a shallow and narrow benthic fringe (Thiel et al. 2007), it could be predicted that an increase in hypoxic areas could negatively impact this ecosystem service, even in natural hypoxic systems. Functioning would also be affected; our results show there is little overlap in traits between the habitats, implying that functioning cannot be maintained in the same way after changes in species composition. It is worthy to note that in other benthic systems, trawling and dredging fisheries have severely impacted sea floor organisms, leading to drastic changes in structural and functional diversity (Thrush and Dayton 2002; Tillin et al. 2006; Kenchington et al. 2007). In the system studied here, benthic resources (e.g., scallops, snails, limpets, clams and octopus) are caught selectively by divers, which is much less harmful than intensive bottom trawling. However, a single diver can eliminate target species from large areas, potentially altering functioning. For example, Langton and Robinson (1990) found that the decline of $70 \%$ of scallops and $20-30 \%$ of burrowing anemones and fan worms caused by scallop fishing induced a shift in the sediment from organic-rich silty sand to sandy gravel with shell hash. Hence, single or few species removal can have important changes in functioning and should not be overlooked (see also Graham et al. 2006). Likewise, we have described functioning from two sampling stations based on taxa which were representative from similar habitats in other areas in this region. Due to the sampling restriction to these two sites, we likely missed some species and their contribution to the functioning that could be obtained by enhancing the spatial replication. Including several sampling sites is therefore recommended when conducting this type of studies.

The Humboldt Current system is subject to the occurrence of El Niño Southern Oscillation, which can induce either drastic or subtle changes in soft-bottom benthic diversity and community structure (Arntz et al. 2006). For hypoxic habitats off central Peru and northern Chile taxa, diversity tends to increase during El Niño events, as a result of improved conditions brought about by increments of dissolved oxygen and temperature (Tarazona et al. 1988a, b, 1996; Moreno et al. 2008). These diversity changes are thought to be a consequence of ecological succession to more mature stages (Tarazona et al. 1988a, b, 1996; Thatje et al. 2008). Furthermore, changes in bottom water dissolved oxygen and organic matter in the sediment during El Niño 1997-1998 have lead to variations in the bioturbation potential of macrobenthos off central Chile (Gutiérrez et al. 2000). Therefore, we predict that functional diversity will change in hypoxic habitats during El Niño events, as conditions become more similar to those of normoxic areas. Studies conducted during and after El Niño events will confirm whether these expectations are realized and information gleaned from such studies can lead to a better understanding of the behavior of marine ecosystem processes during climate variability.

Acknowledgments We appreciate the help of many students from the Facultad de Recursos del Mar, Universidad de Antofagasta, particularly Alexis Maffet and Karen Chamblas for their support during field trips and samples sorting. Guillermo Guzman provided much taxonomic guidance. Comments by two anonymous reviewers help us to improve an early draft of this manuscript. This study was funded by the Alfred Wegener Institute for Polar and Marine Research in cooperation with the Instituto de Investigaciones Oceanologicas, Universidad de Antofagasta and the EU-funded INCO project, "Climate Variability and El Niño-Southern Oscillation: Implications for Natural Coastal Resources and Management" (CENSOR) and Programa Bicentenario de Ciéncia y Tecnología RUE-02.

\section{References}

Arntz W, Gallardo V, Gutiérrez D, Isla E, Levin L, Mendo J, Neira C, Rowe GT, Tarazona J, Wolff M (2006) El Niño and similar perturbation effects on the benthos of the Humboldt, California and Benguela current upwelling ecosystems. Adv Geosci 6:243-265 
Barber R, Smith R (1981) Coastal upwelling ecosystems. In: Longhurst AR (ed) Analysis of marine ecosystems. Academic Press, New York, pp 31-68

Bremner J (2008) Species' traits and ecological functioning in marine conservation and management. J Exp Mar Biol Ecol 366:37-47

Bremner J, Rogers SI, Frid CLJ (2003) Assessing functional diversity in marine benthic ecosystems: a comparison of approaches. Mar Ecol Prog Ser 254:11-25

Bremner J, Paramor OAL, Frid CLJ (2006) Developing a methodology for incorporating ecological structure and function into designation of special areas of conservation (SAC) in the 0-12 nautical mile zone. Report to English Nature. School of Biological Sciences, University of Liverpool

Buchanan JB (1984) Sediments analysis. In: Methods for the study of marine benthos. IBP Hand Book 16, Black Well SCI, Pub. $158 \mathrm{pp}$

Carrasco FD (1997) Sublittoral macrobenthic fauna off Punta Coloso, Antofagasta, northern Chile: high persistence of the polychaete assemblage. Bull Mar Sci 60:443-459

Carrasco FD, Moreno RA (2006) Long-term dynamics (1990 to 2004) of the polychaete fauna from the sublittoral soft-bottoms off Punta Coloso (Antofagasta), northern Chile. Sci Mar 70:169-178

Chevenet F, Dolédec S, Chessel D (1994) A fuzzy coding approach for the analysis of long-term ecological data. Freshw Biol 31:295-309

Christensen V, Pauly D (1993) Flow characteristics of aquatic systems. In: Christensen V, Pauly D (eds) Trophic models of aquatic ecosystems. ICLARM, conference Proceedings, vol 26, Manila, pp 338-352

Collie JS, Hall SJ, Kaiser MJ, Poiner IR (2000) A quantitative analysis of fishing impacts on shelf-sea benthos. J Anim Ecol 69:785-798

de Bello F, Lavorel S, Diaz S, Harrington R, Cornelissen JHC, Bardgett RD, Berg MP, Cipriotti P, Feld CK, Hering D, Martins de Silva P, Potts SG, Sandin L, Paulo Sousa J, Storkey J, Wardle D, Harrison PA (2010) Towards an assessment of multiple ecosystem processes and services via functional traits. Biodivers Conserv 19:2873-2893

Díaz S, Cabido M (2001) Vive la différence: plant functional diversity matters to ecosystem process. Trends Ecol Evol 16:646-655

Diaz RJ, Rosenberg R (2008) Spreading dead zones and consequences for marine ecosystems. Science 321:926-929

Escribano R (1998) Population dynamics of Calanus chilensis from northern Chile. Fish Oceanogr 7:245-251

Escribano R, Hidalgo P (2000) Spatial distribution of copepods in the north of the Humboldt Current region off Chile during coastal upwelling. J Mar Biol Ass UK 80:283-290

Escribano R, Marín V, Hidalgo P, Olivares G (2002) Physicalbiological interactions in the pelagic ecosystem of the nearshore zone of the northern Humboldt Current System. In: Castilla JC, Largier J (eds) The oceanography and ecology of the nearshore bays in Chile. Proceedings of the international symposium on linkages and dynamics of coastal systems: open coast and embayments. Ediciones Universidad Católica de Chile, Santiago de Chile, pp 145-175

Fauchald K, Jumars PA, Johnson BA, Boudreau BB (1979) The diet of worms: a study of polychaete feeding guilds. Oceanogr Mar Biol Ann Rev 17:193-284

Ferdelman T, Lee C, Pantoja S, Harder J, Bebout B, Fossing H (1997) Sulfate reduction and methanogenesis in a Thioploca dominated sediment off the coast of Chile. Geochim Cosmochim Ac 61:3065-3079

Folk R, Ward W (1957) Brazos River bar, a study in the significance of grain-size parameters. J Sed Petrol 27:3-27
Gabriel KR (1971) The biplot graphic display of matrices with application to principal component analysis. Biometrika 58:453-467

Gabriel KR (2002) Goodness of fit of biplots and correspondence analysis. Biometrika 89:423-436

Giraldo A, Escribano R, Marín V (2002) Spatial distribution of Calanus chilensis off Mejillones Peninsula (northern Chile): ecological consequences upon coastal upwelling. Mar Ecol Prog Ser 230:225-234

Graham NAJ, Wilson SK, Jennings S, Polunin NVC, Bijoux JP, Robinson J (2006) Dynamic fragility of oceanic coral reef ecosystems. Proc Nat Acad Sci USA 103:8425-8429

Gutiérrez D, Gallardo VA, Mayor S, Neira C, Vásquez C, Sellanes J, Rivas M, Soto A, Carrasco F, Baltazar M (2000) Effects of dissolved oxygen and fresh organic matter on the bioturbation potential of macrofauna in sublittoral sediments off Central Chile during the 1997/1998 El Niño. Mar Ecol Prog Ser 202:81-99

Heip CHR, Duineveld G, Flach E, Graf G, Helder W, Herman PMJ, Lavaleje M, Middelburg JJ, Pfannkuche O, Soetaert K, Soltwedel T, de Stigter H, Thomsen L, Vanaverbeke J, de Wilde P (2001) The role of the biota in sedimentary metabolism and sediment-water exchange process in the Goban Spur are (NE Atlantic). Deep Sea Res II 48:3223-3243

Jackson JBC (1977) Competition on marine hard substrata: the adaptive significance of solitary and colonial strategies. Am Nat 111:743-767

Jones CG, Lawton JH, Shachak M (1994) Organisms as ecosystem engineers. Oikos 69:373-386

Jørgensen BB, Gallardo VA (1999) Thioploca spp.: filamentous sulfur bacteria with nitrate vacuoles. FEMS Microbiol Ecol 28:301-313

Kenchington EL, Kenchington TJ, Henry LA, Fuller S, Gonzalez P (2007) Multi-decadal changes in the megabenthos of the Bay of Fundy: the effects of fishing. J Sea Res 58:220-240

Lancellotti DA, Stotz WB (2004) Effects of shoreline discharge of iron mine tailings on a marine soft-bottom community in northern Chile. Mar Pollut Bull 48:303-312

Langton RW, Robinson WE (1990) Faunal association on scallop grounds in the Western Gulf of Maine. J Exp Mar Biol Ecol 144:157-171

Laudien J, Rojo M, Oliva M, Arntz W, Thatje S (2007) Sublittoral soft bottom communities and diversity of Mejillones Bay in northern Chile (Humboldt Current upwelling system). Helgoland Mar Res 61:103-116

Levin LA (2003) Oxygen minimum zone benthos: adaptations and community response to hypoxia. Oceanogr Mar Biol Ann Rev 41:1-45

Levins R, Lewontin R (1985) The dialectical biologist. Harvard University Press, Cambridge

Levinton JS (1995) Bioturbators as ecosystem engineers: population dynamics and material fluxes. In: Jones CG, Lawton JH (eds) Linking species and ecosystems. Chapman and Hall, New York

Lohrer AM, Thrush SF, Gibbs MM (2004) Bioturbators enhance ecosystem function through complex biogeochemical interactions. Nature 431:1092-1095

Lohrer AM, Thrush SF, Hunt L, Hancock N, Lundquist C (2005) Rapid reworking of subtidal sediments by burrowing spatangoid urchins. J Exp Mar Biol Ecol 321:155-169

Lomovasky B, Mendez A, Brey T, Iribarne O (2006) The effect of the SW Atlantic burrowing crab Chasmagnathus granulatus on the intertidal razor clam Tagelus plebeius. J Exp Mar Biol Ecol 337:19-29

Marchini A, Munari C, Mistri M (2008) Functions and ecological status of eight Italian lagoons examined using biological traits analysis (BTA). Mar Pollut Bull 56:1076-1085 
Marin VH, Escribano R, Delgado LE, Olivares G, Hidalgo P (2001) Nearshore circulation in a coastal upwelling site off the Northern Humboldt current system. Cont Shelf Res 21:1317-1329

Meysman FJR, Middelburg JJ, Heip CHR (2002) Bioturbation: a fresh look at Darwin's last idea. Trends Ecol Evol 12:688-695

Moreno RA, Sepúlveda RD, Badano EI, Thatje S, Rozbaczylo N, Carrasco FD (2008) Subtidal macrozoobenthos communities from northern Chile during and post El Niño 1997-1998. Helgoland Mar Res 62(Suppl 1):45-55

Naeem S (2002) Ecosystem consequences of biodiversity loss: the evolution of a paradigm. Ecology 83:1517-1552

Norling K, Rosenberg R, Hulth S, Grémare A, Bondsforff E (2007) Importance of functional biodiversity and species-specific traits of benthic fauna for ecosystem functions in marine sediment. Mar Ecol Prog Ser 332:11-23

Odling-Smee FJ, Laland KN, Feldman MW (1996) Niche construction. Am Nat 147:641-648

Ortiz M, Wolff M (2002a) Trophic models of four benthic communities in Tongoy Bay (Chile): comparative analysis and preliminary assessment of management strategies. J Exp Mar Biol Ecol 268:205-235

Ortiz M, Wolff M (2002b) Dynamical simulation of mass-balance trophic models for benthic communities of north-central Chile: assessment of resilience time under alternative management scenarios. Ecol Model 148:277-291

Pagliosa PR (2005) Another diet of worms: the applicability of polychaeta feeding guilds as a useful conceptual framework and biological variable. Mar Ecol 26:246-254

Pagliosa PR, Rodrigues FA (2006) Assessing the environmentbenthic fauna coupling in protected and urban areas of southern Brazil. Biol Conserv 129:408-417

Palma M, Quiroga E, Gallardo V, Arntz W, Gerdes D, Schneider W, Hebblen D (2005) Macrobenthic animal assemblages of continental margin off Chile $\left(22^{\circ}\right.$ to $\left.42^{\circ} \mathrm{S}\right)$. J Mar Biol Ass UK 85:233-245

Pearson TH, Rosenberg R (1978) Macrobenthic succession in relation to organic enrichment and pollution of the marine environment. Oceanogr Mar Biol Ann Rev 16:229-311

Quinn G, Keough M (2002) Experimental design and data analysis for biologists. Cambridge University Press, Cambridge

Quiroga E, Soto R, Vargas M, Guzman G, Cifuentes S, Navarrete N (1999) Abundance and composition of the sublittoral macrozoobenthos in four shallow areas off northern Chile $\left(18^{\circ} 30^{\prime} \mathrm{S}-\right.$ $\left.23^{\circ} 04^{\prime} \mathrm{S}\right)$. Invest Cienc Tecnol Ser Cienc Mar Universidad Arturo Prat 5:30-37

Quiroga E, Quiñones R, Palma M, Sellanes J, Gallardo VA, Gerdes D, Rowe G (2005) Biomass size-spectra of macrobenthic communities in the oxygen minimum zone off Chile. Estuar Coast Shelf Sci 62:217-231

Reise K (1985) Tidal flat ecology. An experimental approach to species interactions. Ecological studies. Springer, Berlin

Reise K (2002) Sediment mediated species interactions in coastal waters. J Sea Res 48:127-141

Sandnes J, Forbes T, Hansen R, Sandnes B, Rygg B (2000) Bioturbation and irrigation in natural sediments, described by animal-community parameters. Mar Ecol Prog Ser 197:169-179

Sebens KP (1982) Competition for space: growth rate, reproductive output, escape size. Am Nat 120:189-197

Sebens KP (1986) Spatial relationships among encrusting marine organisms in the New England subtidal zone. Ecol Monogr 56:73-96
Sellanes J, Quiroga E, Neira C, Gutiérrez D (2007) Changes of macrobenthos composition under different ENSO cycle conditions on the continental shelf off central Chile. Cont Shelf Res 27:1002-1016

Southwood TRE (1977) Habitat, the templet for ecological strategies? J Anim Ecol 46:336-365

Tarazona J, Arntz W (2001) The Peruvian coastal upwelling system. In: Seeliger U, Kjerfve B (eds) Coastal marine ecosystems of Latin America, Ecological Studies vol 144. Springer, Berlin

Tarazona J, Salzwedel H, Arntz WE (1988a) Oscillations of macrozoobenthos in shallow waters of the Peruvian central coast induced by El Niño 1982-1983. J Mar Res 46:593-661

Tarazona J, Salzwedel H, Arntz WE (1988b) Positive effects of "El Niño" on macrozoobenthos inhabiting hypoxic areas of the Peruvian upwelling system. Oecologia 76:184-190

Tarazona J, Arntz WE, Canahuire E (1996) Impact of two "El Niño" events of different intensity on the hypoxic soft bottom macrozoobenthos off the central Peruvian coast. PSZN Mar Ecol 17:425-446

Taylor HM, Wolff M, Vadas F, Yamashiro C (2008) Trophic and environmental drivers of the Sechura bay ecosystem (Perú) over an ENSO cycle. Helgoland Mar Res 62(Suppl 1):15-32

Thatje S, Heilmayer O, Laudien J (2008) Climate variability and El Niño Southern Oscillation: Implications for Natural Coastal Resources and Management. Helgoland Mar Res 62(Suppl 1): $5-14$

Thiel M, Macaya EC et al (2007) The Humboldt Current system of northern and central Chile: oceanographic processes, ecological interactions and socioeconomic feedback. Oceanogr Mar Biol Ann Rev 45:195-344

Thrush SF, Dayton PK (2002) Disturbance to marine benthic habitats by trawling and dredging: implications for marine biodiversity. Annu Rev Ecol Syst 33:449-473

Tillin HM, Hiddink JG, Jennings S, Kaiser MJ (2006) Chronic bottom trawling alters the functional composition of benthic invertebrate communities on a sea-basin scale. Mar Ecol Prog Ser 318:31-45

Townsend CR, Hildrew AG (1994) Species traits in relation to a habitat templet for river systems. Freshw Biol 31:265-275

Townsend CR, Dolédec S, Scrarsbrook M (1997) Species traits in relation to temporal and spatial heterogeneity in streams: a test of habitat templet theory. Freshw Biol 37:367-387

Ulanowicz RE (1986) Growth \& development: ecosystems phenomenology. Springer, New York

Ulanowicz RE (1997) Ecology, the ascendent perspective. Columbia University Press, New York

Valdés J, Román D, Dávila P, Ortlieb L, Guíñez M (2006) Seasonal variability of cadmium in a coastal upwelling system of northern off Chile (Mejillones bay, $23^{\circ} \mathrm{S}$ ). Rev Chil Hist Nat 79:517-535

Vivanco M (1999) Análisis estadístico multivariable teoría y práctica, 2nd edn. Editorial Universitaria, Santiago de Chile

Warwick RM, Ashman CM, Brown AR, Clarke KR, Dowell B, Hart B, Lewis RE, Shillabeer N, Somerfield PJ, Tapp JF (2002) Interannual changes in the biodiversity and community structure of the macrobenthos in Tees Bay and the Tees Estuary, UK, associated with local and regional environmental events. Mar Ecol Prog Ser 234:1-13

Witman JD, Dayton PK (2001) Rocky subtidal communities. In: Bertness MD, Gaines SD, Hay ME (eds) Marine community ecology. Sinauer Associates Inc, Sunderland, pp 339-366 